\title{
Serum interleukin-6 and -10 levels in patients with gastric cancer
}

\author{
Masahide Ikeguchi, Tomoko Hatada, Manabu Yamamoto, Takanori Miyake, Tomonori Matsunaga, \\ Youji Fukumoto, Yoshinori Yamada, Kenji Fukuda, Hiroaki Saito, and Shigeru Tatebe \\ Department of Surgery, Division of Surgical Oncology, Faculty of Medicine, Tottori University, 36-1 Nishi-cho, Yonago 683-8504, Japan
}

\begin{abstract}
Background. Interleukin-6 (IL-6) is known to be a multifunctional cytokine and IL-10 is an immunosuppressive factor. Both have been reported to be related to the disease prognosis in some human solid tumors. In the present study, we evaluated the clinical significance of preoperative serum IL-6 and IL-10 levels as new tumor markers in patients with gastric cancer (GC).

Methods. Preoperative serum samples from 90 patients with GC and 9 normal healthy volunteers were assayed. Levels of IL-6 and IL-10 were determined by enzyme-linked immunosorbent assay (ELISA). The clinical significance of serum IL-6 and IL-10 levels was evaluated and compared with serum carcinoembryonic antigen (CEA) levels and serum $C$-reactive protein (CRP) levels in these patients.

Results. The serum level of IL-6 was significantly higher in the GC patients than in the healthy subjects. Serum IL-6 levels were strongly correlated with CRP levels, but did not correlate with CEA or carbohydrate antigen (CA) 19-9 levels. Serum IL-10 levels did not correlate with CEA, CA19-9, or CRP. Strong positive correlations between serum IL-6 levels and tumor size and tumor stage were observed. On the other hand, IL-10 did not correlate with such clinicopathological findings of tumors. However, high serum IL-10 levels were associated with a worse prognosis in the GC patients, independently of their tumor stage.

Conclusion. These findings indicate that serum IL-6 may suggest gastric cancer progression. On the other hand, IL-10 may play an important role in host immunity and the prognosis of GC patients.
\end{abstract}

Key words Gastric cancer · Interleukin-6 · Interleukin-10 • Tumor marker

Offprint requests to: $\mathrm{M}$. Ikeguchi

Received: November 11, 2008 / Accepted: April 8, 2009

\section{Introduction}

Several serum markers have been used in the detection of progression of gastric cancer (GC). Recently, several studies have demonstrated that high preoperative serum levels of carcinoembryonic antigen (CEA), carbohydrate antigen (CA) 19-9, or of CA72-4 were correlated with lymph node metastasis, liver metastasis, or peritoneal metastasis in patients in the advanced stages of GC $[1,2]$. However, these markers are not useful for the detection of early-stage GC. Also, it is well known that many patients with advanced GC show normal serum levels of these markers. Thus, new biological serum markers are needed for the detection of GC.

Interleukin-6 (IL-6), a multifunctional cytokine produced by both hematopoietic cells and epithelial cells, plays a central role in host defense mechanisms [3]. Recently, Leu et al. [4] demonstrated that many esophageal carcinoma tissues expressed IL- 6 mRNA and that IL-6 protein protected an esophageal carcinoma cell line from apoptosis induced by staurosporine. IL- 6 is also reported to be produced by other epithelial tumors [5]. Increased serum IL-6 levels have been found in patients with multiple myeloma [6], renal cell carcinoma [7], bladder carcinoma [8], head and neck cancer [9], ovarian cancer [10], and cholangiocarcinoma [11].

Interleukin-10 (IL-10), on the other hand, is a pleiotropic cytokine produced by macrophages, T-helper 2 cells, and B lymphocytes (CD5 subset) and can both stimulate and suppress the immune response [12]. IL-10 has been shown to inhibit various immune functions, such as antigen presentation, cytokine production, macrophage activation, and antigen-specific T-cell proliferation. By interfering with antigen-presenting cells, IL-10 reduces antigen-specific T-cell proliferation. Moreover, IL-10 has been proposed to play a key role in the oncogenetic and metastatic ability of neoplasms [13, 14]. Increased levels of serum IL-10 have been found in patients with solid and hematopoietic tumors [15-17]. 
The present study was designed to investigate the clinical usefulness of serum levels of IL- 6 and IL-10 as new tumor markers for patients with GC, in comparison with serum CEA and CA19-9 levels.

\section{Patients and methods}

\section{Samples}

Preoperative serum samples from 90 patients (mean age, 65.8 years; range, 36-88 years; male, 65; female, 25) with GC who were treated at Tottori University Hospital between 2001 and 2004 were assayed. No patient had received preoperative chemotherapy. Eighty-five patients underwent gastrectomy; however, in the remaining 5 patients, gastrectomy was not performed, because metastases were widely detected in the peritoneal cavity. The patients were staged according to the Japanese classification of gastric carcinoma [18]. The number of patients at each tumor stage was as follows: stage I, $n=43$, stage II, $n=10$; stage III, $n=21$; and stage IV, $n=16$. All patients were followed until April 2007. The mean follow up was 37 months (range, 3-76 months). The causes of death were determined from clinical findings. Serum samples were also obtained from nine normal healthy blood donors (mean age, 59.8 years; range, 44-77 years; male, 8, female, 1) as controls. The normal volunteers had no history of gastrointestinal complaints. Informed consent was obtained from all patients and all normal healthy donors for the use of their samples to detect serum levels of IL-6 and IL-10. The present study conformed to the ethical standards of the World Medical Association Declaration of Helsinki and was approved by the Ethics Committee of Tottori University Faculty of Medicine (no 448).

\section{Analysis of serum levels of IL-6 and IL-10}

Serum samples were kept at $-80^{\circ} \mathrm{C}$ until use and thawed immediately before the determination of the cytokine levels. Serum IL-6 and IL-10 levels were determined using enzyme-linked immunosorbent assay (ELISA) kits (Quantikine; R\&D Systems, Minneapolis, MN, USA) according to the manufacturer's instructions. All samples were measured in duplicate.

\section{Detection of serum tumor markers and C-reactive protein $(C R P)$}

Preoperative serum tumor markers (CEA and CA19-9) and CRP were routinely measured in patients with GC at our hospital. Serum CEA levels less than $5 \mathrm{ng} / \mathrm{ml}$, serum CA19-9 levels less than $35 \mathrm{U} / \mathrm{ml}$, and serum CRP levels less than $0.2 \mathrm{mg} / \mathrm{dl}$ were taken as the normal ranges $[19,20]$.

\section{Statistical analysis}

Spearman's rank correlation coefficient was used to assess correlations between the levels of cytokines and the levels of tumor markers or CRP in GC patients. The comparison of IL- 6 and IL-10 in relation to the tumor stage and histological variables was assessed by the Kruskal-Wallis test and Mann-Whitney $U$-test. Survival rates were calculated by the Kaplan-Meier method. Survival curves were compared using the log-rank test. Univariate and multivariate analyses of prognosis for GC patients were performed using the Cox proportional hazards model. Statistically significant difference was defined as $P<0.05$.

\section{Results}

\section{Serum IL-6 and IL-10 levels}

The mean serum IL- 6 level of the 90 patients with GC (5.8 pg/ml; range, $0-277.5 \mathrm{pg} / \mathrm{ml}$ ) was significantly higher than that of the 9 healthy volunteers $(0.1 \mathrm{pg} / \mathrm{ml}$; range, $0-1.0 \mathrm{pg} / \mathrm{ml} ; P<0.001)$. However, even though the mean serum IL-10 level of the 90 patients with GC $(12.5 \mathrm{pg} /$ $\mathrm{ml}$, range, $0-309.3 \mathrm{pg} / \mathrm{ml}$ ) was higher than that of the 9 healthy volunteers $(4.0 \mathrm{pg} / \mathrm{ml}$; range, $0.6-19.8 \mathrm{pg} / \mathrm{ml})$, the difference was not significant $(P=0.061)$. No correlation was observed between IL-6 levels and IL-10 levels in 99 samples ( 90 from GC patients and 9 from the healthy volunteers; $\rho=0.148, P=0.163$ ).

\section{Correlation between serum cytokine levels and tumor markers or CRP in GC patients}

In the GC patients, the mean CEA level was $6.6 \mathrm{ng} / \mathrm{ml}$ (range, $0.1-92.6 \mathrm{ng} / \mathrm{ml}$ ), the mean CA19-9 level was $27.3 \mathrm{U} / \mathrm{ml}$ (range, $0.1-336 \mathrm{U} / \mathrm{ml}$ ), and the mean CRP level was $0.25 \mathrm{mg} / \mathrm{dl}$ (range, $0.03-2.55 \mathrm{mg} / \mathrm{dl}$ ). A significant positive correlation was found between CEA and CA19-9 levels $(\rho=0.264, P=0.017)$. However, the levels of CEA and CA19-9 did not correlate with CRP levels in the GC patients $(\rho=0.129, P=0.478$ and $\rho=$ $0.059, P=0.75)$. Serum IL-6 levels were strongly correlated with CRP levels $(\rho=0.487, P<0.001)$, but they did not correlate with CEA $(\rho=0.096, P=0.381)$ or CA19-9 $(\rho=0.05, P=0.651)$. On the other hand, serum IL-10 levels did not correlate with CEA $(\rho=0.13$, $P=0.235)$, CA19-9 $(\rho=0.002, P=0.983)$, or CRP $(\rho=0.19, P=0.297)$. 
Correlation between serum cytokine levels and clinicopathological features of the patients

Tumor sizes were measured in the 85 resected specimens. In the five patients in whom gastrectomy was not performed because of advanced tumors, tumor size was measured by X-ray films. The mean tumor size in the $90 \mathrm{GC}$ patients was $6.4 \mathrm{~cm}$ (range, $1-25 \mathrm{~cm}$ ). The correlation between tumor size and the levels of tumor markers and cytokines is indicated in Table 1. We found a strong positive correlation between tumor size and serum IL-6 levels.

The cutoff values of CEA, CA19-9, and CRP were established at $5 \mathrm{ng} / \mathrm{ml}, 35 \mathrm{U} / \mathrm{ml}$, and $0.2 \mathrm{mg} / \mathrm{dl}$, respectively, according the manufacturer's protocol in our hospital. The cutoff values of IL- 6 and IL-10 were determined according to the values in healthy volunteers (mean $+2 \times \mathrm{SD}$; IL-6, $0.8 \mathrm{pg} / \mathrm{ml}$; IL-10, $14 \mathrm{pg} / \mathrm{ml}$ ) as described previously $[21,22]$. High CEA levels were found in 17 of the $90 \mathrm{GC}$ patients (18.9\%), high CA19-9 levels were found in 13 (14.4\%), high CRP levels were found in $14(15.5 \%)$, high IL-6 levels were found in 53 $(58.9 \%)$, and high IL-10 levels were found in 11 (12.2\%). We show the correlations between the levels of tumor markers and cytokines and clinicopathological features

Table 1. Correlation between tumor size and serum levels of CEA, CA19-9, CRP, IL-6, and IL-10 detected by Spearman's rank correlation coefficient

\begin{tabular}{lcc}
\hline & $\rho$ & $P$ \\
\hline CEA & 0.146 & 0.185 \\
CA19-9 & 0.159 & 0.153 \\
CRP & 0.152 & 0.413 \\
IL-6 & 0.286 & 0.008 \\
IL-10 & 0.084 & 0.436 \\
\hline
\end{tabular}

of the 90 patients in Table 2. We found that a high serum CEA level was clearly correlated with the depth of tumor invasion and lymph node metastasis. Also, high serum IL-6 levels were found in 13/32 (40.6\%) of the patients with T1 depth of tumor invasion, 17/28 $(60.7 \%)$ of those with T2, 16/22 $(72.7 \%)$ of those with $\mathrm{T} 3$, and $7 / 8(87.5 \%)$ of those with T4. Thus, the serum IL-6 level correlated with GC invasion. But it did not correlate with lymph node metastasis. Serum CA19-9, CRP, and IL-10 did not correlate with GC progression (Table 2).

\section{Prognostic significance of IL-6 and IL-10 in GC patients}

The patients were divided into two subgroups according to the cutoff values of CEA, CA19-9, CRP, IL-6, and IL-10. Survival curves were compared between the two subgroups. The overall 5-year survival rate of the 90 patients was $57.2 \%$. Table 3 lists the prognostic factors of the patients and shows the results of the univariate survival analysis. Serum CEA, IL-6, and IL-10 levels were found to be strong prognostic factors, like tumor stage, for patients with GC. Figure 1 shows the survival curves of patients with high and low levels of serum IL-6 and IL-10. In multivariate survival analyses of four parameters (tumor stage, CEA, IL-6, and IL-10), serum IL-10 level was recognized as a poor prognostic marker independent of tumor stage (Table 3).

\section{Discussion}

In the present study, serum IL-6 levels in gastric cancer (GC) patients were significantly higher than those in healthy subjects. We found that serum IL-6 levels were

Table 2. Correlation between clinicopathological characteristics and tumor markers, CRP, and serum cytokine levels (\%)

\begin{tabular}{|c|c|c|c|c|c|c|}
\hline & $n$ & $\begin{array}{l}\text { High levels } \\
\text { of CEA }\end{array}$ & $\begin{array}{c}\text { High levels } \\
\text { of CA19-9 }\end{array}$ & $\begin{array}{c}\text { High levels } \\
\text { of CRP }\end{array}$ & $\begin{array}{l}\text { High levels } \\
\text { of IL-6 }\end{array}$ & $\begin{array}{c}\text { High levels } \\
\text { of IL-10 }\end{array}$ \\
\hline \multicolumn{7}{|l|}{ Histological type } \\
\hline Differentiated & 41 & $7(17.1)$ & $7(17.1)$ & $8(19.5)$ & $23(56.1)$ & $6(14.6)$ \\
\hline Undifferentiated & 49 & $10(20.4)$ & $6(12.2)$ & $6(12.2)$ & $30(61.2)$ & $5(10.2)$ \\
\hline$P$ & & 0.687 & 0.516 & 0.469 & 0.623 & 0.523 \\
\hline \multicolumn{7}{|c|}{ Depth of tumor invasion } \\
\hline $\mathrm{T} 1$ and $\mathrm{T} 2$ & 60 & $6(10)$ & $6(10)$ & $5(8.3)$ & $30(50)$ & $7(11.7)$ \\
\hline $\mathrm{T} 3$ and $\mathrm{T} 4$ & 30 & $11(36.7)$ & $7(23.3)$ & $9(30)$ & $23(76.7)$ & $4(13.3)$ \\
\hline$P$ & & 0.002 & 0.089 & 0.072 & 0.015 & 0.82 \\
\hline \multicolumn{7}{|c|}{ Lymph node metastasis } \\
\hline Absent & 50 & $5(10)$ & $5(10)$ & $8(16)$ & $26(52)$ & $6(12)$ \\
\hline Present & 40 & $12(30)$ & $8(20)$ & $6(15)$ & $27(67.5)$ & $5(12.5)$ \\
\hline$P$ & & 0.016 & 0.179 & 0.955 & 0.138 & 0.943 \\
\hline \multicolumn{7}{|l|}{ Tumor stages } \\
\hline I and II & 53 & $6(11.3)$ & $5(9.4)$ & $8(15.1)$ & $26(49.1)$ & $7(13.2)$ \\
\hline III and IV & 37 & $11(29.7)$ & 8 (21.6) & $6(16.2)$ & $27(73)$ & $4(10.8)$ \\
\hline$P$ & & 0.028 & 0.106 & 0.798 & 0.023 & 0.733 \\
\hline
\end{tabular}


Table 3. Univariate and multivariate survival analyses of possible prognostic factors

\begin{tabular}{|c|c|c|c|c|c|}
\hline & \multirow[b]{2}{*}{$n$} & \multicolumn{2}{|c|}{ Univariate } & \multicolumn{2}{|c|}{ Multivariate } \\
\hline & & 5-Year survival rate (\%) & $P$ & Risk ratio & $P$ \\
\hline \multicolumn{6}{|l|}{ Tumor stages } \\
\hline I and II & 53 & 82.2 & $<0.001$ & 8.333 & $<0.001$ \\
\hline III and IV & 37 & 21.6 & & & \\
\hline \multicolumn{6}{|l|}{ CEA } \\
\hline Low $(<5 \mathrm{ng} / \mathrm{ml})$ & 73 & 62.4 & 0.016 & 1.055 & 0.889 \\
\hline High $(\geq 5 \mathrm{ng} / \mathrm{ml})$ & 17 & 35.3 & & & \\
\hline \multicolumn{6}{|l|}{ CA19-9 } \\
\hline Low $(<35 \mathrm{U} / \mathrm{ml})$ & 77 & 60.6 & 0.161 & - & - \\
\hline $\operatorname{High}(\geq 35 \mathrm{U} / \mathrm{ml})$ & 13 & 36.9 & & & \\
\hline \multicolumn{6}{|l|}{ CRP } \\
\hline Low $(<0.2 \mathrm{mg} / \mathrm{dl})$ & 62 & 66.7 & 0.104 & - & - \\
\hline $\operatorname{High}(\geq 0.2 \mathrm{mg} / \mathrm{dl})$ & 28 & 42.9 & & & \\
\hline \multicolumn{6}{|l|}{ IL-6 } \\
\hline Low $(<0.8$ pg/ml $)$ & 37 & 70.2 & 0.013 & 1.264 & 0.532 \\
\hline $\operatorname{High}(\geq 0.8 \mathrm{pg} / \mathrm{ml})$ & 53 & 47.8 & & & \\
\hline \multicolumn{6}{|l|}{ IL-10 } \\
\hline Low $(<14$ pg/ml $)$ & 79 & $61.6 \%$ & 0.045 & 2.761 & 0.047 \\
\hline $\operatorname{High}(\geq 14$ pg/ml $)$ & 11 & $27.3 \%$ & & & \\
\hline
\end{tabular}

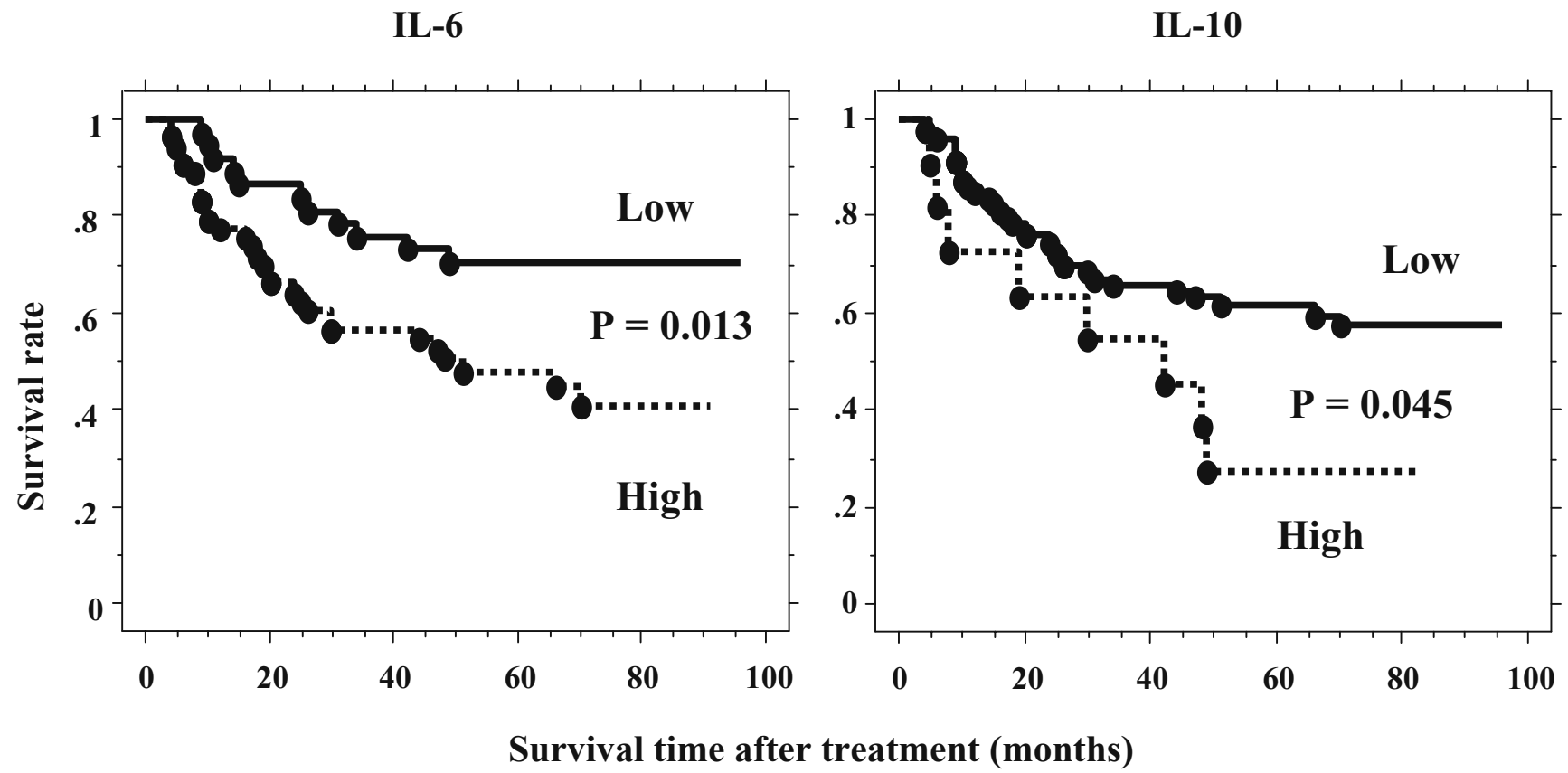

Fig. 1. Overall survival curves of the patients. Left, the survival curve of patients with low levels of serum interleukin-6 (IL-6; $n=37$, solid line) was significantly better than that of patients with high levels of serum IL-6 $(n=53$, dotted line; $P=0.013)$. Right, the survival curve of patients with low levels of serum IL-10 $(n=79$, solid line $)$ was significantly better than that of patients with high levels of serum IL-10 $(n=11$, dotted line; $P=0.045)$

positively correlated with serum CRP levels and the size of tumors in patients with GC. We found a significant positive correlation between serum IL-6 level and depth of tumor invasion. But we found no significant correlation between serum IL-6 level and lymph node metastasis in GC patients. These findings indicate that serum
IL-6 in patients with GC may reveal the degree of damage of the gastric wall caused by ulcerative reaction of the tumor. Serum IL-6 is known to be produced by both hematopoietic cells and epithelial cells. Serum IL6 is regarded as the major mediator of CRP synthesis in hepatocytes [23]. 
Thus, IL-6 is a potent proinflammatory cytokine that plays a central role in the systemic inflammatory response. Also, IL-6 is reported to stimulate B-cell and hematopoietic stem cell growth and is reported to correlate with megakaryocyte maturation and macrophage differentiation [22]. Ito et al. [24] reported that three of eight GC cell lines secreted IL-6 into the culture media and GC cell growth was stimulated by the secreted IL-6; they concluded that IL-6 was an autocrine growth stimulator for GC. Leu et al. [4] have reported that IL-6 binds to IL-6 receptors and homodimerizes with gp130. This homodimer activates Janus kinase (JAK) and also activates signal transducers, such as transcription 3 (STAT3). The JAK/STAT3 pathway may play a role in mediating cell growth. Also, Ashizawa et al. [22] found a strong positive correlation between serum IL-6 levels and GC tissue IL-6 protein expression levels detected by immunostaining. Thus, IL-6 may contribute to the progression of GC in an autocrine or paracrine manner.

On the other hand, we found that serum IL-10 did not correlate with depth of tumor invasion, lymph node metastasis, or tumor stage. IL-10 may be produced as an anti-inflammatory cytokine. The anti-inflammatory characteristics of IL-10 downregulate the host immune response [25]. A high IL-10 level was suggested to contribute to a relative state of immunosuppression in patients with hepatocellular carcinoma [26]. Matsuguchi et al. [27] reported that high serum IL-10 levels in patients with hepatocellular carcinoma presumably also resulted from the secretion of IL-10 by tumor cells. Sakamoto et al. [28] demonstrated that IL-10 expression was found in $48 \%$ of GC tissues by immunohistochemistry. They found that tumor IL-10 expression was strongly correlated with depth of tumor invasion and with lymph node metastasis, and that IL-10 expression was inversely correlated with CD8+ T-lymphocyte infiltration. In the present study, we found that a high level of serum IL-10 was detected in only $12 \%$ of GC patients and did not correlate with tumor progression; however, it correlated with a poor prognosis for the patient. These findings suggest that a high serum level of IL-10 may correlate with reduced host immunity.

We found that IL-10 levels were not related to those of IL-6. This finding suggests that an independent response may occur between IL-10 and IL-6 in GC. Our multivariate analysis showed serum IL-10 levels to be an independent prognostic factor. In addition, even though there was a significant difference in survival between patients with high levels of serum IL-6 and those with low levels, serum IL-6 levels were not independent of tumor stage. In our study, elevated IL-10 levels had no correlation with other adverse prognostic factors, including tumor size and tumor stage. These findings indicate that serum IL-6 levels may correlate with GC progression, and that serum IL-10 levels may correlate with depressed immunity of the host.

High circulating and local levels of IL-10 may be produced by tumor cells or other cells, and may contribute to the development of an environment favorable to neoplastic cells, by reducing host local immunity, and by enhancing the metastatic potential of neoplastic cells. If this hypothesis is true, the inhibition of IL-10 production or the administration of anti-IL-10 agents could become a new therapeutic tools for treating patients with GC.

\section{References}

1. Guadagni F, Roselli M, Amato T, Cosimelli M, Mannella E, Perri $\mathrm{P}$, et al. Tumor-associated glycoprotein-72 serum levels complement carcinoembryonic antigen levels in monitoring patients with gastrointestinal carcinoma. A longitudinal study. Cancer 1991;68: 2443-50.

2. Ikeguchi M, Katano K, Saitou H, Tsujitani S, Maeta M, Kaibara N. Pre-operative serum levels of CA72-4 in patients with gastric adenocarcinoma. Hepatogastroenterology 1997;44:866-71.

3. Hirano T, Akira S, Taga T. Biological and clinical aspects of interleukin-6. Immunol Today 1990;11:443-9.

4. Leu CM, Wong FH, Chang C, Huang SF, Hu CP. Interleukin-6 acts as an antiapoptotic factor in human esophageal carcinoma cells through the activation of both STAT3 and mitogen-activated protein kinase pathways. Oncogene 2003;22:7809-18.

5. Watson JM, Sensintaffar JL, Berek JS, Martinez-Maza O. Constitutive production of IL-6 by ovarian cancer cell lines and by primary ovarian tumor cultures. Cancer Res 1990;50:6959-65.

6. Bataille R, Jourdan M, Zhang XG, Klein B. Serum levels of interleukin 6 , a potent myeloma growth factor, as a reflection of disease severity in plasma cell dyscrasias. J Clin Invest 1989;84: 2008-11.

7. Tsukamoto T, Kumamoto Y, Miyao N, Masumori N, Takahashi A, Yanase M. Interleukin-6 in renal cell carcinoma. J Urol 1992;148:1778-82.

8. Seguchi T, Yokokawa K, Sugao H, Nakano E, Sonoda T, Okuyama A. Interleukin-6 activity in urine and serum in patients with bladder carcinoma. J Urol 1992;148:791-4.

9. Gallo O, Gori AM, Attanasio M, Martini F, Paola G, Storchi OF, et al. Acute-phase proteins and interleukin-6 serum level in head and neck cancer. Arch Otolaryngol 1992;118:1336-7.

10. Berek JS, Chung C, Kaldi K, Watson JM, Knox RM, Martínez-Maza O. Serum interleukin-6 levels correlate with disease status in patients with epithelial ovarian cancer. Am J Obstet Gynecol 1991;164:1038-43.

11. Goydos JS, Brumfield AM, Frezza E, Booth A, Lotze MT, Carty SE. Marked elevation of serum interleukin- 6 in patients with cholangiocarcinoma. Validation of utility as a clinical marker. Ann Surg 1998;227:398-404.

12. Howard M, O'Garra A, Ishida H, de Waal Malefyt R, de Vries J. Biologic properties of interleukin-10. J Clin Immunol 1992;12: 239-47.

13. Holland G, Zlotnik A. Interleukin-10 and cancer. Cancer Invest 1993;11:751-8.

14. Nabioullin R, Sone S, Mizuno K, Yano S, Nishioka Y, Haku T, et al. Interleukin-10 is a potent inhibitor of tumor cytotoxicity by human monocytes and alveolar macrophages. J Leukocyte Biol 1994;55:437-42.

15. Fortis C, Foppoli M, Gianotti L, Galli L, Citterio G, Consogno $\mathrm{G}$, et al. Increased interleukin-10 serum levels in patients with solid tumors. Cancer Lett 1996;104:1-5. 
16. Merville P, Rousset F, Banchereau J, Klein B, Betaille R. Serum interleukin-10 in early stage multiple myeloma. Lancet 1992;340: 1544-5.

17. Blay JY, Burdin N, Rousset F, Lenoir G, Biron P, Philip T, et al. Serum interleukin-10 in non-Hodgkin's lymphoma: a prognostic factor. Blood 1993;82:2169-74.

18. Japanese Gastric Cancer Association. Japanese classification of gastric carcinoma — 2nd English edition. Gastric Cancer 1998;1: $10-24$.

19. Choi SR, Jang JS, Lee JH, Roh MH, Kim MC, Lee WS, et al. Role of serum tumor markers in monitoring for recurrence of gastric cancer following radical gastrectomy. Dig Dis Sci 2006; 51:2081-6.

20. Yamashita H, Kitayama J, Nagawa H. Hyperfibrinogenemia is a useful predictor for lymphatic metastasis in human gastric cancer. Jpn J Clin Oncol 2005;35:595-600.

21. Ikuta S, Miki C, Tanaka K, Konishi N, Mohri Y, Tonouchi H, et al. Serum immunosuppressive acidic protein as an interleukin-6 related index of deteriorating condition in gastric cancer patients. Dig Surg 2003;20:532-8.

22. Ashizawa T, Okada R, Suzuki Y, Takagi M, Yamazaki T, Sumi T, et al. Clinical significance of interleukin-6 (IL-6) in the spread of gastric cancer: role of IL-6 as a prognostic factor. Gastric Cancer 2005;8:124-31.
23. Castell JV, Gomes-Lechon MJ, David M, Fabra R, Trullenque R, Heinrich PC. Acute-phase response of human hepatocytes: regulation of acute-phase protein synthesis by interleukin-6. Hepatology 1990;12:1179-86.

24. Ito R, Yasui W, Kuniyasu H, Yokozaki H, Tahara E. Expression of interleukin-6 and its effect on the cell growth of gastric carcinoma cell lines. Jpn J Cancer Res 1997;88:953-8.

25. Moore KW, O'Garra A, de Waal Malefyt R, Vieira P, Mosmann TR. Interleukin 10. Annu Rev Immunol 1993;11:165-90.

26. Chau GY, Wu CW, Lui WY, Chang TJ, Kao HL, Wu LH, et al. Serum interleukin-10 but not interleukin-6 is related to clinical outcome in patients with resectable hepatocellular carcinoma. Ann Surg 2000;231:552-8.

27. Matsuguchi I, Okamura S, Kawasaki C, Niho Y. Production of interleukin-6 from human liver cell lines: production of interleukin-6 is not concurrent with the production of $\alpha$ fetoprotein. Cancer Res 1990;50:7457-9.

28. Sakamoto T, Saito H, Tatebe S, Tsujitani S, Ozaki M, Ito H, et al. Interleukin-10 expression significantly correlates with minor CD8+ T-cell infiltration and high microvessel density in patients with gastric cancer. Int J Cancer 2006;118:1909-14. 